\title{
Chapter 4 \\ Traditional Teaching-Learning Process in the Class of Polish School Through Lens of UDL Approach
}

\author{
Jolanta Baran (1), Tamara Cierpialowska (1), and Ewa Dyduch (i)
}

\begin{abstract}
Education researchers have long advocated modifications to the teaching-learning process in order to make the school a more inclusive space and conducive to individual and group development of students with diverse (including special) educational needs. This is to develop competences, skills and values that will allow students to better prepare for adult life in a rapidly changing world. This demand is not new and is not only a demand but refers to reforming the education process. In Poland, for many years the schools have been undergoing dynamic changes in many different dimensions, partly because of facilitating students with special needs. In the considerations of education researchers, as well as in the daily educational practice of teachers, the question arises as to what should be done to optimise the teaching-learning process and how. One possible idea for such optimisation is to implement the Universal Design for Learning (UDL) approach. The purpose of this chapter is to seek an answer to the question of to what extent the reality of the Polish schools corresponds to the principles of the UDL. An analysis of the traditional learning process through the UDL lens has identified those areas in which UDL approach solutions are provided and also where it is worthwhile to implement them.
\end{abstract}

Keywords Traditional teaching - Integrated education - Inclusive education · Universal design for learning $\cdot$ Teaching-learning process

\footnotetext{
J. Baran $(\varangle) \cdot$ T. Cierpiałowska $\cdot$ E. Dyduch

Pedagogical University of Krakow, Krakow, Poland

e-mail: Jolanta.Baran@up.krakow.pl; tamara.cierpialowska@up.krakow.pl;

ewa.dyduch@up.krakow.pl
} 


\subsection{Introduction: Realities and Challenges of Contemporary School Education in Poland}

Inclusion as a promoted system of education is not yet fully implemented in Poland. The Ministry of Education is working on a project to transform existing education into inclusive education, which is still scheduled for public consultation. During the process of transforming conventional Polish education into inclusive education, the intermediate link has become integrated education. ${ }^{1}$ Such a form was developed and implemented over the last two decades. Despite some benefits, many researchers have indicated that it did not work as effectively as it was supposed to, neither for students with special educational needs nor for those without such requirements (e.g., Gajdzica, 2014; Janiszewska-Nieścioruk, 2009; Parys, 2007).

From the segregated model (separate schools and other teaching methods for students with disabilities) which dominated to the end of the 1990s, through integrated teaching (common classes available for small groups of students with disabilities in each), we are now entering the era of the inclusive school. This is not just about integrating pupils with special needs into public schools, but about understanding that every student is different, everyone has their own difficulties and limitations (which can have very different sources) and above all, that everyone has their own potential, which is worth focusing on and which can be developed.

What we observe today is that the concept of pupils with special educational needs is also changing. It is no longer just students with disabilities, chronic diseases or the most talent; many other different factors are identified that may cause the modern student to present needs that require an individual approach from the teacher on a permanent or temporary basis. The variety of students with special education needs (SEN) comes from social changes and migration.

Inclusion is meant as a three-level process (Gajdzica, 2019, 32; Szumski, 2019):

- Open social environment-inclusion, providing people with special educational needs (including disabilities) with an opportunity to implement developmental tasks, function in a larger community and feel a sense of belonging.

- The strategy of the education system-educational inclusion, providing children/students with special educational needs with access to mainstream kindergartens/schools and local educational institutions, taking into account an environment that is individually adapted and minimally restrictive for the development of a student with disabilities. The main categories that construct the educational inclusion strategy are diversity, equality of access, equity, school for all,

\footnotetext{
${ }^{1}$ This is one of three available forms of education for children with SEN in Poland. In integrated education, it is essential that the teaching and upbringing process is properly organised. Integrated classes are set up for children/students with certified special education needs in public kindergartens/schools/settings. Integrated classes are less numerous, attended by a maximum of 15 students without disabilities and a maximum of five students with special educational needs and/or disabilities. There are two teachers in an integrated class during the lesson, with a so-called leading teacher and supporting teacher.
} 
a universal (common) curriculum, balanced learning objectives, taking into account the harmonious development of students, a flexible support system for professionals working together and an inclusive school culture. Participants in the inclusion process are: students with special needs, parents/guardians, teachers, other professionals and peer and local communities. Inclusive education should ensure that all participants in this process are provided with a favourable environment.

- Educational impact - inclusive education understood as a process of joint education of students with special development and educational needs with their peers, ensuring a sense of belonging to the local community and providing the necessary support (technical, methodical, psychosocial, organisational) resulting from special educational needs. The key to an inclusive approach should be to differentiate teaching content and methods according to the student's needs, which is the essence of respecting individual differences.

The very important issue in transforming school into a new school-for example, into an inclusive school in Poland-is remodelling the traditional didactics. As the Universal Design for Learning (UDL) approach is perceived as one of these that might support transformation (Szumski, 2019), it is worth analysing the weaknesses and strengths of teachers' practice and routines through the lens of the UDL approach for identifying the phenomena that need change (see Table 1.1 in Chap. 1).

The didactics textbooks emphasise that education is inextricably linked to the training process while education is 'teaching and learning ... with the accompanying bringing-up activities’ (Półturzycki, 2014, 26). The teaching process is defined as 'the totality of conscious, planned and systematic didactic and educational impacts on pupils ... to provide them (students) with an education' (Kupisiewicz \& Kupisiewicz, 2009, 87).

In the teaching process, the teacher is assigned a leading role. They carry out planned and systematic work with students and its effect, in the traditional sense, is to 'master the messages, skills and habits recommended by the curriculum' (Kupisiewicz \& Kupisiewicz, 2009, 110). In a more contemporary approach, however, it is emphasised that the aim of teaching should be to develop learning skills (Jastrzębska, 2011), hence the aim of any teacher's activities is not so much to convey knowledge but to support students in the learning process in organising and facilitating learning for pupils (Półturzycki, 2014), including self-discovery of knowledge and even the construction of knowledge (Klus-Stańska, 2019).

It is considered that the most effective education method is, therefore, an eclectic method, activating all the senses of the learners, as well as requiring them to combine the previously acquired knowledge with new content and experience in solving a particular case or problem (Silberman, 2005). Such conditions, due to the diverse students, meet the UDL approach, as was already mentioned. It is also important to take into account the students' learning styles (Silberman, 2005).

Emphasis is placed, therefore, on the importance of not only preparing teachers for the profession but also the teacher's continuous work on her or himself. It is 
crucial to constantly develop their pedagogical, didactic, methodological and communication competences.

The second process of education, that is learning, is directly related to the students: 'It is a process in which, on the basis of experience, cognition and exercise, new forms of behaviour and action are created or the forms previously acquired change' (Okoń, 2004, 433; Półturzycki, 2014; Kupisiewicz \& Kupisiewicz, 2009). Learning is the process of 'intentionally acquiring certain messages, skills and habits, taking place in the course of direct and/or indirect knowledge of reality' (Kupisiewicz \& Kupisiewicz, 2009, 184). The drivers of this process are primarily the student's own activity and strong internal motivation (Okoń, 2004). Teaching and learning processes are inextricably linked, and each of them has its own indisputable importance. What matters, however, is how they are distributed. Cooperation is strongly involved in these processes and becomes a prerequisite for the students' success. When a teacher interacts with students, both school actors perform similar roles (Kujawiński, 2010):

- A planner, for example, during the co-planning of a class programme of school and out-of-school activities for students

- An evaluator, for example, when co-evaluating student performance

- An observer, for example, while co-persuasive with each other in the joint performance of complex problem tasks

- An advisor, for example, when co-counselling each other on the selection and use of sources of information

- A helper, for example, when helping each other to understand something very difficult or ambiguous

- A researcher, for example, in the course of co-examining a natural, social or other phenomenon

- A creator/wizard, such as when co-creating ideas to solve open problem tasks or other difficulties

- An implementer, for example, when co-executing complex problem tasks

- An initiator, for example, when co-initiating some important teaching, educational or caring activities

Thus, the roles performed by the teacher and the student are balanced in the teaching-learning situations, regardless of the differently computed responsibility of each of them. The UDL approach respects such roles and helps in their development (see Chap. 1). 


\subsection{Methodological Assumptions on Teaching-Learning Process Analysis Through the Lens of UDL Implementation}

According to the definition of the research subject it is "everything that represents the so-called social reality, that is, communities and social collections, social institutions, social processes and phenomena' (Sztumski, 1995, 7). Following this approach, the subject of the research presented here was one class (at the beginning of the research in the school year 2018/2019 it was elementary school Class V) consisting of 17 students (including some students with SEN) and a team of four teachers in this class. The aim was to simultaneously capture the process of teaching-learning taking place in the examined community, as school education is understood as an interactive relationship between two simultaneous subprocesses: teaching (teacher activity and reflectiveness) and learning (student activity and reflectiveness). Thus, the main focus of the researchers was to examine the teaching-learning process in the researched class when comparing to the main characteristics of the UDL approach (see Table 1.1 in Chap. 1). The results were needed for identifying the educational conditions for implementing the UDL approach in that class in the best possible way. It was also clear to the researchers that such aims need to include a few steps: identifying barriers and conditions conducive to innovation in the learning process, that is by familiarising and proposing to teachers the implementation of the UDL approach and supporting them in implementing innovation to optimise the teaching-learning process in the diverse class team.

We have found the UDL approach to be an excellent way to make a difference in the learning process and to take a step towards inclusive education, since the basic principles of this approach provide an opportunity to organise high-quality, inclusive education that meets the diverse needs of all students. These principles include (Meyer et al., 2014):

- Providing multiple means of commitment

- Providing multiple means of representation

- Providing multiple means of action and expression

The research questions for the research were formulated as follows:

- What does the teaching-learning process look like in the researched class when comparing to the main characteristics of the UDL approach?

The above question was specified further with the use of the UDL approach characteristics:

- How do teachers and students perceive students' diversity in the classroom and what does that mean to them?

- How do teachers differentiate the learning environment (methods, sources of knowledge, educational resources) so that students can achieve their lesson goals? 
- How do teachers and students perceive collaboration and what does that mean to them?

Further, the second main question was added:

- What are the barriers vs. conditions that might support transformation of the teaching-learning process in the class through implementation of the UDL approach?

The research was carried out using the mixed method approach with the emphasis on the action research method (Szymańska et al., 2018; Szymańska, 2018; Czerepaniak-Walczak, 2014; Pilch \& Bauman, 2010; Sagor, 2008). This methodology made it possible to blur the boundary between theory and practice, as action research 'is a systematic collection of information about phenomena that cause some changes, with the researcher being an inspirer and active participant of events. Research in action is carried out when one sees the possibility of changing a situation for the better, prepares a project to improve it, puts it into practice and observes what resulted from all this' (Pilch \& Bauman, 2010, 307). An unquestionable advantage of action research is the fact that its informal character makes it possible to improve the pedagogue's workshop and serve to improve educational and teaching practice (Pilch \& Bauman, 2010; Czerepaniak-Walczak, 2014).

The framework of the research process was designed in reference to action research cycles and covered:

1. The research issues (mentioned as of yet)

2. Action plan:

- Try to convince teachers and students to implement changes, for example, to change the place of individual students and the teacher's position in the classroom during work (moving away from whole-class teaching to promoting cooperation between students).

- Familiarize teachers with the principles of the UDL and show examples; there were concerns about how to implement UDL in the classroom at the basic level.

3. Synthetic description of the actions taken in this cycle:

- Suggestions to teachers on how to give choices to students and arrange teamwork in a different classroom space.

- Passing the floor to the students/activating students' initiatives through:

- joint design of an ideal classroom space

- making students reflect on their expectations towards the teaching/learning process (free talk about: What would be the ideal lesson you would like to take part in?)

- Offer students self-diagnosis for their learning process to recognize their own learning style

- Suggestions for teachers on how to differentiate between teaching and learning activities, taking into account different learning styles 
For data collection, the following techniques and tools were used:

- Survey of teachers, students and their parents based on a questionnaire, which is a compilation of tools by Markowska \& Szafraniec (1980), Sendyk (2001) and Zamkowska (2009).

- Participant observation of the activities of teachers and students during the selected lessons.

- Interviews with students on the following topic: What would be the ideal lesson you would like to take part in?

- Focus group interview with students-discussion to help students recognize their own learning style and ability to choose effective learning strategies.

- Focus group interview with teachers about the values of the UDL and their implementation options in their own educational practice and suggestions for teachers on how to differentiate activities (choice of purpose, working method(s), didactic means, forms of work) in the teaching-learning process, taking into account different learning styles of students.

The constant comparative method was used to analyse the content of interviews and both quantitative and qualitative data collected by surveys (Creswell, 2013). The constant comparative method was applied to identify topics and their specific threads in the data obtained through the research process, which were previously transcribed and encoded.

The UDL lens (see Table 1.1 in Chap. 1) was also adopted for analysis of the results, so some specific phenomena were recognised while work was done on the data collected. The main attention was driven to:

- Teachers' and students' perception of diversity in the classroom and the origins of educational difficulties

- Differentiation of learning environment (methods, sources of knowledge, educational resources) by teachers for achieving the lesson goals by students

- The experience of students-students and teacher-students collaboration

- Barriers versus strengths that might support transformation of the teachinglearning process in the class through implementation of the UDL approach towards inclusive education

- Students' attitude to the school and their duties

In order to ensure the accuracy and reliability of the analyses presented below, a communicative validation procedure was applied (Szmidt \& ModrzejewskaŚwigulska, 2015). It consists in presenting the subjects and threads selected in the analysis process and reconciliation of the interpretations made with them.

As previously mentioned, the research covered one class of a public elementary school with integrated settings in a large Polish city with the population exceeding 750,000 inhabitants. At the start of the research project, that is in December of the school year 2018/2019, it was Class V of an integrated form; the students were then 11-12 years old. The research took place just over one semester, that is until the end of the school year. 
The class team representing the object of the research is - in accordance with the educational law in force in Poland - the integrated form (Dyduch, 2012; Dziennik Ustaw, 2015, poz. 1113; Szumski, 2006). Several students in this class have special educational needs assessment, which means that these students have a disability of some kind or learning disorders. Other students do not have such documents, but this does not mean that they do not have different/diverse educational and developmental needs, including special ones. To define them, the strengths and weaknesses of each student in the class were also identified.

For the sake of ethical standards of the research process, it is important to emphasise that prior to the project's start, parents were asked to give written permission for their child to participate in the research, including recording interviews with students and observing their actions during lessons. The aim of ensuring high ethical standards in the research was also to ensure the anonymity of the persons surveyed, by means of confidentiality of the so-called sensitive data. While interviewing students, the principle of voluntary participation was applied each time.

The community of active researchers consisted of four teachers of the studied class, including three leading subject lessons and one assistant, who accompanied the students during most of the lessons, as well as three researchers from the Institute of Special Needs Education at the Pedagogical University of Kraków. This enabled the triangulation of empirical data (Kubinowski, 2010).

\subsection{Teaching-Learning Process in an Integrated Class: Analysis of Teachers' and Students' Roles and Activities Through the Lens of the UDL Approach}

To develop good conditions for UDL approach implementation in the selected class, it was necessary to identify the main characteristics of the teaching-learning process in which the teachers and students were involved so far. In this way, further research was planned that was meant to support the strategy to incentivise teachers and students to change their routine activities in the teaching-learning process. To make a proper identification of teachers' resources feasible, their beliefs and professional experience, as well as gaining knowledge about students, were supposed to enable the choice of strategy and adaptation of researchers' communication with the teachers, and ultimately to develop a plan for researchers' visits to the school and to negotiate the goals of the teachers themselves. The data collected were structured and prepared to present the main characteristics of the use of the UDL approach (UDL lens) and the specified research questions. 


\section{Teachers' and Students' Perception of Diversity in the Classroom and the Origins of Educational Difficulties}

A prerequisite for the implementation of the teaching-learning process in accordance with the UDL approach is a good knowledge of the students. The analysis shows that teachers know their students well and easily identify their strengths and weaknesses. They provided detailed information about students. When characterizing students with SEN, a specific term was usually given about the disorder they were diagnosed with, such as Asperger syndrome, dyslexia, aphasia, etc. What is more, at least one positive and negative trait has been assigned to each student. The least positive qualities were given to three pupils (only one for each of them), that is he/she is willing to go to school or she/he is polite. Even in positive qualities, the following, for example, were mentioned about students: often distracted, in class she/he takes care of other things, often loses work cards, with low self-activity. This also draws attention to the fact that the teachers' descriptions of the functioning of the students were dominated by their weaknesses.

Students also showed their own reflections on the grades in the teaching-learning process. Sometimes the maturity of the students seemed surprising, as they perceived well the inner diversity of the class teams.

Beata: The grade should perform the function showing the student how he is doing with a particular lesson. It's important that the evaluation criteria are adapted to children. Well, you know, some people have their medical certificates, others, so ... Some are visualizers, others have kinaesthetic skills, and still others are auditory learners. Everybody is different. So everything has to be adjusted. (Reflection with researcher, 1)

Taking into account the diversity of students is the main determinant of the learning activities of the teachers surveyed. Such a picture emerges from the interpretation of detailed answers to questions in the survey about the teaching strategies used. Keeping in mind, the diverse possibilities of pupils, the teachers, above all, clearly individualise the requirements and the way in which knowledge is communicated. They also admit that they rarely take students' interests into account. On the other hand, they individualise the choice of teaching aids for some students according to their abilities. In teacher planning, thinking about students' weaknesses rather than their strengths prevails.

Based on the data collected, one can get the impression that student diversity in the classroom is a challenge that forces teachers, above all, to differentiate expectations and adapt the way they communicate with each student during the lesson. The most common form of teacher action in educational interaction is individualised command simplification.

In teacher perception and activities, the diversity of students divides the team into those who need a different approach (individualisation) and those with whom they can work as a whole/team because of lack of, or rather small, differences.

A good orientation in the strengths and weaknesses of students does not entail a change in the way they think about the sources of their educational difficulties. The subjects consider the causes of educational difficulties within the student with 
special needs. It is worth noting that both teachers and students in the course of interactions activate various ways of supporting them so that their student/colleague does not experience difficulties due to their differences.

\section{Differentiating Learning Environment (Methods, Sources of Knowledge, Educational Resources) by Teachers for Achieving the Lesson Goals by Students}

The survey found (see Table 4.1) that teachers develop their students' knowledge and competences by mainly using traditional methods in the teaching-learning process. However, in a view of the diversity of pupils, they apply, first of all, additional instructions and, as has already been mentioned, simplifying the instructions. They then consider the need to explain incomprehensible terms/words and to give short and precise guidance to the student to help them to be active/to perform tasks. For selected students, they increase the time of exposure and on a specific activity. They find that, uncommonly, they have the opportunity to combine theory with practice.

The assessment of the specific educational strategies mentioned by teachers from the UDL approach perspective leads to the conclusion that teachers apply some of the UDL principles in the teaching process, although without being aware that their chosen activities fall within this concept. However, it should be made clear that they rarely plan and implement solutions that promote the achievement of objectives in

Table 4.1 Strategies used by each teacher by percentage

\begin{tabular}{l|l|l|l|l}
\hline \multirow{2}{*}{\begin{tabular}{l} 
Answers/items \\
\cline { 2 - 5 }
\end{tabular}} & $\begin{array}{l}\text { Teacher and percentage of strategy use } \\
\text { Agnes }(\%)\end{array}$ & $\begin{array}{l}\text { Teacher } \\
\text { Bella }(\%)\end{array}$ & $\begin{array}{l}\text { Teacher } \\
\text { Cecil }(\%)\end{array}$ & $\begin{array}{l}\text { Teacher } \\
\text { Dalia }(\%)\end{array}$ \\
\hline $\begin{array}{l}\text { Delivering the multi-sensory } \\
\text { experiencing of objects }\end{array}$ & 0 & 0 & 30 & 72 \\
\hline $\begin{array}{l}\text { Offering tasks to the best of the student's } \\
\text { ability (student copes with tasks) }\end{array}$ & 18 & 48 & 48 & 30 \\
\hline $\begin{array}{l}\text { Adapting activity to the student's } \\
\text { interests }\end{array}$ & 0 & 6 & 18 & 12 \\
\hline $\begin{array}{l}\text { Creating opportunities to choose } \\
\text { exercises }\end{array}$ & 0 & 12 & 12 & 6 \\
\hline $\begin{array}{l}\text { Teaching theory in conjunction with } \\
\text { practice }\end{array}$ & 18 & 30 & 36 & 60 \\
\hline Working using materials/objects & 48 & 0 & 18 & 18 \\
\hline Providing short and precise guidance & 54 & 42 & 60 & 54 \\
\hline Explaining incomprehensible words & 48 & 36 & 60 & 60 \\
\hline $\begin{array}{l}\text { Simplifying or adopting commands/tasks } \\
\text { Providing additional instructions }\end{array}$ & 42 & 42 & 66 & 36 \\
\hline Extending the time of item exposure & 12 & 54 & 54 & 30 \\
\hline
\end{tabular}

The gray is for UDL strategies 
ways that go beyond the typical/traditional approach. Teachers, therefore, sometimes consider the students' individual learning style, strengths/skills and their interests and adapt the proposed activities to them and organize situations enabling students to choose an exercise or task. It also happens that in addition to the typical materials and help that teachers use to implement the subject of the lesson, they introduce additional materials and aids. They also refer to the presentation of the purpose of the lesson to give examples of the use of learned knowledge in practice. Creating situations in which students seek knowledge or alternative solutions on their own is notable because teachers say they lack time to do so. However, it is possible as a voluntary activity or additional homework.

The analysis of the percentages of teachers' strategies shows that traditional teaching dominates their activities (black letters). Strategies that can be classified as the UDL approach (gray letters) are much less represented. They are least likely to be used by Teacher Agnes and slightly more often by Teacher Bella. Delivering the multi-sensor experiencing of objects, on the other hand, is very often used by Teacher Dalia.

Before the interview, the researchers held classes with students to help them recognise their own style of learning and to introduce students to self-diagnosis for learning. The students quickly drew practical lessons from this knowledge. One of the students (as quoted above), when speaking about the 'ideal lesson', referred to this issue and outlined what should take place in such a lesson:

Beata: There should be a lot of inscriptions in particular. The teacher should write a lot on the board or display inscriptions on the screen, just for the visualisers. Besides, the teacher should speak a lot, speak a lot and clearly, for the auditory learners because they listen. But there should also be something there that, let's say, two minutes exercises, for those kinaesthetic learners to walk around the classroom. And that would be such a perfect lesson. That's exactly what I'd like. We'd do a lot, too, but material must be adapted to the kids. (Reflection with researcher, 1)

In order to recognise how students think about their own educational situation and how teachers work with them, students were interviewed (individually, in dyad, as well as in a single triad, depending on the students' wishes). The interview opening question was as follows: What should the lesson you would like to attend look like?

Meanwhile, the auxiliary, detailed question, asked when students needed additional questions, was: How would a superb classroom look, where you and your colleagues would feel good, where you would learn well?

It turned out that numerous students had no ideas at all. An example of having no idea is shown in the statement given below:

Adam: I do not know. Hard to say so. I have no idea. (Reflection with researcher, 11)

When thinking about the ideal classroom space, some students presented a belief that the status quo is good (and even that it is the best and only possible option) and therefore saw no need for any change: 
Cela: In the first form, we were sitting in such a half circle, but not any longer. Definitely the best idea, it's like now, in such rows, sitting on benches set up in such rows opposite the board. This is the best idea. This is definitely the best layout. (Reflection with researcher, 3)

Beata: As it is, it suits me. (Reflection with researcher, 1)

Dorota: It wouldn't have worked otherwise. (Reflection with researcher, 4)

A large part of the students' statements was concerned with their preferred colors:

Cela: I wish the walls were red. (Reflection with researcher, 2)

Edyta: I wish the classroom was more colourful and brighter. I like pastel colours. (Reflection with researcher, 5)

Some students had ideas, but they quickly perceived the problems involved:

Flora: It'd be fun to sit in the armchairs, I'm sure. But it would be hard for children to focus on learning. ... Puffs would be nice, but I don't know whether they would be conducive to learning. (Reflection with researcher, 9)

Some students shared ideas, not so much about the ideal space of their own classroom, but more broadly, about the school space and the area surrounding the school. All this, however, under the proviso that 'I do not think it will work' or 'but I don't think it's possible'.

Dorota: A mini-bar should be at school. It would be cool to have more modern class. But that's rather impossible. (Reflection with researcher, 4)

Flora: There (next to the school) there are lanes, a mini park could be made here so that you could calm down there during the break between classes. But that would probably hard to implement. (Reflection with researcher, 9)

The ideal classroom was not only about space, but above all about undertaking valuable activities, including those of a charitable nature.

Dorota: To enable our school to participate in such operations, for instance for the shelters, or to bring aid to the poor. (Reflection with researcher, 4)

Flora: For instance, you can arrange team-building evenings with the classmates. At that school where I was previously, our Polish language teacher had organised such literary evenings every two weeks. We would read poems and then some snacks were served. (Reflection with researcher, 9)

The picture of an ideal classroom space emerging from interviews with students leads to the reflection that many students perceived as ideal the typical school class they knew and were used to. The following statement can be used as an example here:

Beata: First of all, this classroom be decorated with various drawings of children hanging here. And this classroom should be varied a great deal. And in general, there should be such equipment for various classes-for mathematics, there should be large triangles; in the geographical classroom, I would like to have different maps, and in general, and on the walls, I would like to have maps so that children could take a closer look. It's already partly there. And that's it. It seems to that it should look like as it is now. (Reflection with researcher, 1)

The analysis of the narrations obtained in the course of the interviews with students in relation to the main question leads to the conclusion that they were not able to imagine lessons other than those in which they had participated so far. This 
attachment to the school routine can be exemplified by a statement by one of the students about the 'ideal lesson' of geography he would like to design:

Cela: At the beginning, the teacher should say 'Today we'll have class on this and that topic' and the students should say 'Oh, that's cool'. Then we will write the topic of the lesson on a blackboard, then we open atlases and maps, and look for a city, and what country it is located in. ... I would say to the students 'open the textbooks please' on page such and such and they would read there. ... At the end of the lesson I would check the presence on a piece of paper... I would ask students to do some homework, for example, from exercise book, also from a textbook, and also from a notebook. (Reflection with researcher, 2)

To the researcher's question: What else could you bring to such a perfect lesson to make it even cooler? The student continued the description of the ideal lesson and gave the answer:

Cela: You could still bring your notebook. (Reflection with researcher, 2)

When asked how students' knowledge could be tested during an ideal class, a girl said:

Gosia: The students should answer the teacher's questions. (Reflection with the researcher, 7)

It should be noted that during this interview, the researcher repeatedly stressed that it is supposed to be an idea for a lesson in which the student would be willing to participate, and that he or she could conceptualise and design it in the way that he or she thought it would be the most interesting, the coolest and without any limitations; that the student could decide for him or herself what the ideal lesson could look like.

Some students revealed their own ideas about how to change the teaching-learning process, but at the same time they also pointed out various problems associated with the implementation of these ideas:

Adam: During physical education classes one person could come up with what kind of exercises we do today, and during next physical education class another person could suggest exercises. But during such classes, it's impossible. (Reflection with researcher, 11)

Flora: It would be nice if there were different school trips related to every subject taught at school, but the teachers say that we wouldn't be able to learn the whole curriculum then. (Reflection with researcher, 9)

Even when researchers presented students with proposals/opportunities for more flexible and creative ways of teaching, some students clearly showed reluctance or even criticism towards such proposals.

The researcher tries to imagine such a situation in history classes. For instance, your teacher comes in and says the following: 'Today we will talk about the sixteenth century. We have discussed the basic, crucial issues together, and now each of you can pick up an issue dating back to the sixteenth century that interests you. Not everybody has to learn the same thing at the same time. Perhaps somebody's interested in, let's say, wars that were waged then. And someone else may be interested, for example, in the arts prevailing in that period. What do you think about it?'

Beata: It seems to me that... No! I think it is a bad idea, because then the knowledge would be fragmented and all... And some would know it and others wouldn't know it, but they 
would know something else. Again, those guys don't have knowledge possessed by these guys. The knowledge would be fragmented. It would not be a good idea! (Reflection with researcher, 1)

Teachers use traditional teaching methods. Knowledge is passed on ('given'); even if problematic methods are used, the teacher is the person who directs the search for knowledge in an authoritarian way, imposing ways of seeking knowledge, controlling this process. They rarely encourage students to look for alternative solutions.

From the teachers' survey statements, a picture emerges of the dominant and therefore traditional role of the teacher in the teaching-learning process. Unbalanced educational interaction comes to the fore. At each stage of the lesson, the teacher usually assumes a role that directs and controls the learning process of the students. Students ask problem questions that the teacher answers, but they rarely use these situations to encourage the student to act independently or to create a situation conducive to the student undertaking independent cognitive work in order to gain experience that allows him or her to become an expert in some chosen field of knowledge or activity. Such actions are shifted to extracurricular activities, for example, informal after-school activities - so called teams for developing students' interests.

As has already been demonstrated, the teachers' survey provided data on the application of combining theory and practice in the teaching process (see Table 4.1). Teachers' responses and students' statements revealed that even if teachers try to implement this teaching strategy, it takes place rather in the initial phase of the lesson as an indication or example of the possibility of applying specific knowledge in a specific situation or conditions, having to do with presenting the purpose of the lesson to the students. Occasionally, certain content or action refers to a specific human activity, and thus illustrates contextually the application of knowledge in practice during the implementation of the subject of the lesson.

\section{The Experience of Students-Students and Teacher- Students Collaboration}

An important or perhaps key aspect of the teaching-learning process that appears in the students' statements is cooperation during the lesson, which is not only perceived as an important but also a difficult area to implement:

Hubert: It would be good to cooperate, but some people can't cooperate. Cooperation is really tough in our class. We could have, for instance, the following arrangement: on Monday someone sits with someone, on Tuesday someone else sits with someone else, and if someone wants to, he sits alone. But some people don't want to. (Reflection with researcher, 6)

The researchers also raised the issue of the roles of the teacher and the students during the teaching-learning process. Students were strongly of the opinion that the leading role in the teaching-learning process belongs to the teacher. 
Beata: I think it's best if the teacher teaches. The best thing to do is for the teacher to teach. (Reflection with researcher, 1)

Students who are encouraged to reflect on how to reduce their teacher's leadership role, while enhancing their commitment and own activity in the learning process were not able to break away from the routine based on their own school experience. Encouraged by the researchers to reflect on how this can be changed, students made proposals that demonstrated the high rigidity of their own thinking on the subject:

Beata: It could be that your teacher says: now read pages 44 and 45 from the textbook and the children will learn the content themselves. Then the teacher will say that there is a chapter that we have to read about something. She will give us start page and end page numbers, and children can learn in this way. They can just (read) from the textbook. They'll do the exercises. (Reflection with researcher, 1)

In their statements about the ideal lesson, the students also outlined the profile of the ideal teacher:

Flora: He/she should be cool for sure. And it's nice when we have such a friendly relationship with the teacher. Because there's always something to say. (Reflection with researcher, 9)

Cela: The teacher should speak in a pleasant voice and not shout. (Reflection with researcher, 2)

Flora: It would be good if always the teacher, not because it is his duty ... should give the floor to the student. However, the students should be told not to make pranks or something, but instead to say something wise. (Reflection with researcher, 9)

The students' and teachers' opinions about cooperation refer to their experience and thinking about the traditional teaching-learning process. They show that student-student cooperation is perceived as conditional and based on individual peer relationships and so-called 'likes and dislikes' of others. However, teacher-student cooperation is being built on the teacher's authority, on her/his good personal characteristics and on traditional perception of professional role by students. These facts could be interpreted as barriers to inclusive education. The transformation of this traditional process of education might be achieved by UDL approach implementation.

\section{Barriers vs. Strengths that Might Support Transformation of the Teaching-Learning Process in the Class Through Implementation of the UDL Approach Towards Inclusive Education}

During the first steps of the project, a meeting (recorded with the consent of the participants) was organised to familiarise teachers with the UDL approach and gather their opinions on it, as well as to discuss with them their daily work at school, including their preferred teaching style. The teachers seemed rather unconvinced 
and distrustful of proposed changes as they were accustomed to their teaching strategies. They listed the formal difficulties and, in their view, objective barriers that would prevent change. The analysis of the recorded interview with the teachers confirmed the expected barriers. The barriers included primarily: barriers inherent in the education system, which are mainly related to official documents and regulations concerning education and teachers'sense of involvement in control and management rigors.

Teachers felt highly responsible for what knowledge their students have and how they are able to use this knowledge, and strongly prefer their own teaching style, which they have developed through years of professional experience.

Teacher Agnes: There are certain conditions and we feel imprisoned by those conditions.

(Reflection with researcher, 14)

Teacher Bella: I am a teacher who is not sick, I always work and have difficulties in implementing the curriculum to its full extent (the so-called 'core curriculum' established by the Ministry of National Education). (Reflection with researcher, 15)

Barriers inherent in the teachers here are personal, related to their beliefs and professional experience. After a suggestion to give students a better chance of working in groups, some teachers found that group work makes the classroom noisy and loud, which gives the impression of chaos they do not like.

Teacher Agnes: I'm annoyed by the noise. (Reflection with researcher, 14)

Teacher Cecil: The group was delighted and I was upset. I gave them assignments-

there was chaos and noise. (Reflection with researcher, 16)

Teacher Agnes: It is not possible for every student to succeed in class. I won't hold a class like this in my life. (Reflection with researcher, 14)

The discomfort caused by a change in the way students work with them made it difficult for teachers to accept that even temporary noise and apparent lack of order in the classroom does not have to last long and is an expression of creative action, leading to a failure to see the possible positive results associated with student activity and performance and the satisfaction of both students and teachers.

\section{Students'Attitude to the School and Their Duties}

The collected empirical data, that is students' statements from the surveys, were compared with those of their parents. None of the parents stated that their child did not like going to school while one of the students gave a categorically negative answer. Almost all students surveyed felt safe at school and all parents were fully convinced about this fact. When asked about the motivation and activity during lessons only few students remarked that they were used to being motivated and active. Most of them confessed that they were not very much engaged in learning at school. Almost half of them seemed to strongly prefer the art and physical education classes to maths, history or Polish language lessons. 


\section{Teachers' Professional Qualifications and Students' and Their Parents' Opinion} on Them The team of teachers involved in the research had very good professional qualifications and experience. They took care of their professional development and their knowledge. They took many courses that gave them practical guidance for teaching diverse groups of students, for example, therapy and education of children and adolescents with autism and Asperger's syndrome, education of students with hearing impairments and education of students with intellectual disability (see Table 4.2).

Apart from closed and semi-open questions, the survey forms also contained open ones. As part of the open questions, students were asked to describe their teachers. The terms they used most often concerned both personal and professional competences and were as follows: helpful in learning, kind, patient, good, trustworthy, consistent, caring, cool, cheerful, kind and peaceful.

On the other hand, the parents emphasised the professional competence of the educators working with their children, saying: they understand the needs of the students, teach well, teach in an unconventional manner and deal well with conflicts and difficult behaviours of students. They not only listed both positive and negative

Table 4.2 The teachers' professional qualifications

\begin{tabular}{|c|c|c|c|}
\hline Symbol & $\begin{array}{l}\text { Total } \\
\text { experience in } \\
\text { teaching }\end{array}$ & $\begin{array}{l}\text { Educational } \\
\text { background } \\
\text { (teaching training } \\
\text { level) }\end{array}$ & Extra courses \\
\hline $\begin{array}{l}\text { Teacher } \\
\text { Agnes }\end{array}$ & 29 years & $\begin{array}{l}\text { Pedagogical } \\
\text { faculty, M.A. }\end{array}$ & $\begin{array}{l}\text { Postgraduate studies in education of students with } \\
\text { hearing impairments } \\
\text { Qualification course in education of students with } \\
\text { intellectual disability }\end{array}$ \\
\hline $\begin{array}{l}\text { Teacher } \\
\text { Bella }\end{array}$ & 15 years & M.Sc. & $\begin{array}{l}\text { Post-graduate courses: IT applications } \\
\text { Pedagogical course } \\
\text { Qualification course in studies in education of } \\
\text { students with hearing impairments and with } \\
\text { intellectual disability } \\
\text { Numerous courses on working with autistic } \\
\text { spectrum students }\end{array}$ \\
\hline $\begin{array}{l}\text { Teacher } \\
\text { Cecil }\end{array}$ & 22 years & M.A. & $\begin{array}{l}\text { Postgraduate courses: therapy and education of } \\
\text { children and adolescents with autism and } \\
\text { Asperger's syndrome, qualification course in } \\
\text { education of students with hearing impairments } \\
\text { and with intellectual disability } \\
\text { Argumentative and alternative communication- } \\
\text { conference, numerous courses, safety training } \\
\text { (drugs, aggression, cyberbullying), student } \\
\text { motivation }\end{array}$ \\
\hline $\begin{array}{l}\text { Teacher } \\
\text { Dalia }\end{array}$ & 2 years & $\begin{array}{l}\text { B.A. } \\
\text { M.A. }\end{array}$ & $\begin{array}{l}\text { Postgraduate studies therapy and education of } \\
\text { children and young people with autism and } \\
\text { Asperger's syndrome } \\
\text { Courses on working with dyslexic students, } \\
\text { preventing peer violence and conflict resolution }\end{array}$ \\
\hline
\end{tabular}


personal traits concerning a particular teacher but also generalised them, saying: nice, wise, have a sense of humour, demonstrate peacefulness, patience, perseverance, show fair treatment, demanding, one of them shouts at the students and one does not express his opinion. The statements of both students and parents are consistent in assessing the students' positive affection for all their teachers.

\subsection{Discussion and Conclusions: What Is Worth Doing}

The presented results reflected using the UDL approach lenses indicated some important barriers for transformations towards inclusive education (see Fig. 4.1). The first one was called teachers' and students' perception of diversity in the classroom and the origins of educational difficulties and was highlighted by showing the way the teachers worked with students at different levels of functioning. The research was started with a survey, whose findings indicated that students from the class were a team that varied in terms of individual and special educational needs, motivation and learning style, as well as manifested interests. They were also found to vary in terms of their motivation to learn, skills, learning styles and interests. It turned out that among them there were students with primarily artistic interests

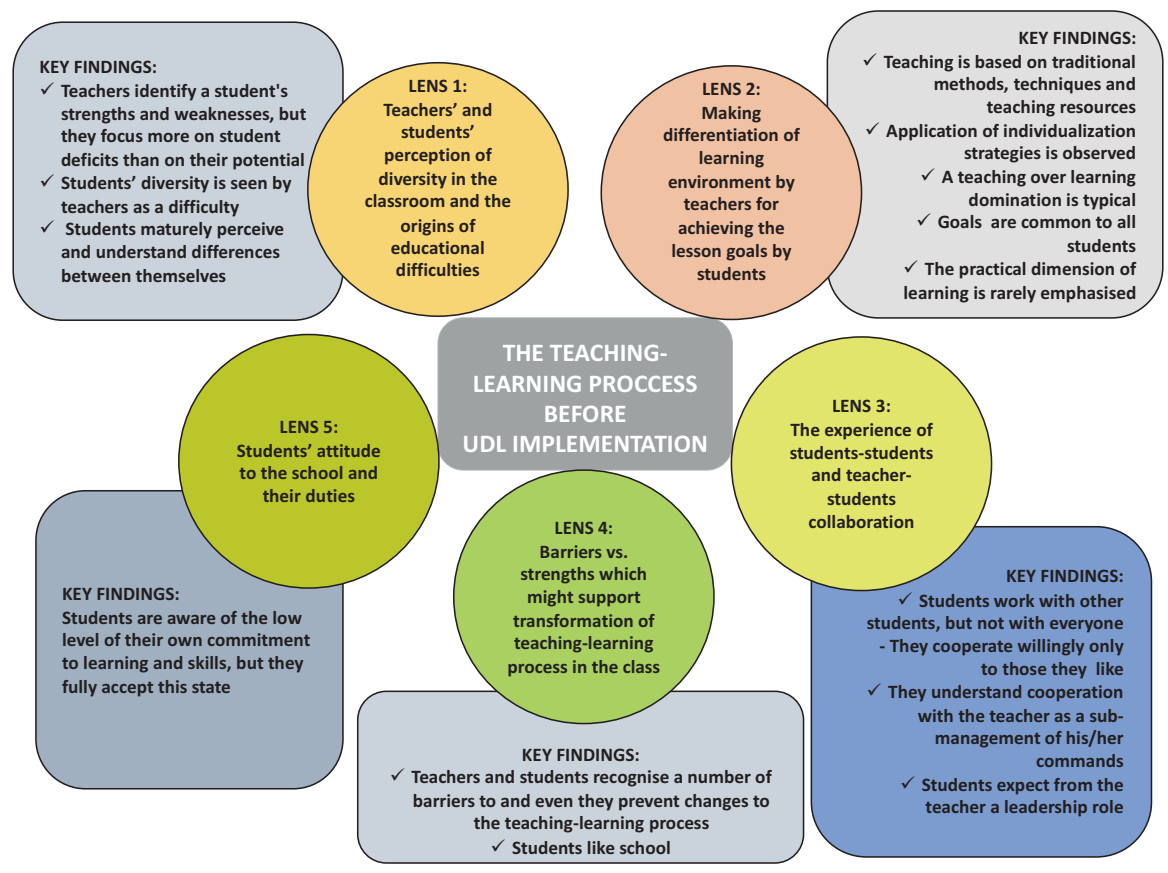

Fig. 4.1 Traditional teaching-learning process—analysis through lens of UDL 
(music, art), whereas interests in history, information technology or geography were identified individually.

In casual talks and interviews with teachers and students it was found that teachers and students were reconciled with the current school environment, that is with conventional, routine teaching-learning. They felt safe in this environment. It can be considered that such a conservative approach is a result of the negative impact of reforms introduced every couple of years by the Ministry of National Education since the first profound change in the education system in 1999. Teachers also followed the cultural changes in the world and, being aware of the increasing pace of changes, seemed to be tired of the feeling of instability and the constant need to adapt to changes, which will either turn out to be bogus changes or will require new competences, knowledge updates, etc. (Knasiecka-Falbierska, 2013; Śliwerski, 2013). The students also disclosed that they were used to routine activities that gave them a feeling of comfort. When asked about their proposals for changes concerning teaching-learning and in school life, both of them expressed their reconciliation with the status quo and their concern about the changes proposed to them by researchers. Their statements also showed a lack of faith in the success of any change.

It could be that the pessimism shown by teachers and students is rather a fear of the need to develop new strategies for adaptation and emancipation through education, requiring personal development and demanding the application of new strategies in the teaching-learning process (Czerepaniak-Walczak, 2006).

The data collected made it possible to identify the factors inherent in the daily routines of teachers and the students' attitudes, whose permanency was considered to be important barrier to encourage UDL approach implementation and thus to initiate changes in the realities of the surveyed class. It was assumed that this was just a portion of various obstacles that occurred in making differentiation of learning environment (methods, sources of knowledge, educational resources) by teachers for achieving the lesson goals by students. In relation to the individual and special needs of students, the preliminary study interviewed teachers about the use and adaptation of methods while working with students. Their statements confirm the use of rather conventional teaching strategies and teachers not enough paying attention to the personalisation of students' work and the use of less conventional means and forms of activity. However, they consider the diversity of students and make an attempt to modify their procedures. Most often this is related to the provision of additional instructions/information and to the simplification of instructions. Meanwhile, the least frequent activities of students are those matched with their interests, in which they are offered opportunities to pick up exercises/tasks on their own. Thus, the survey showed that teachers used traditional and routine teaching strategies, although they tried to adapt them to the needs and capabilities of students. The most common of these strategies were the provision of additional instructions and information, and the simplification of instructions. The teaching and learning process, in this period of our action research, was characterised by a rather passive attitude of the students towards the leading teacher. In the interviews held with teachers and students in the class understudy, it was found that they tolerated and even fully accepted the existing school reality and such a teaching-learning 
process. What is more, disbelief in the success of the proposed change involving the implementation of the UDL approach and even fear of it was recognised. This was related to the fear of losing the sense of security that is given by being in the familiar, predictable reality.

Thus, analyses of the collected results showed that both teachers and students were used to traditional, routine teaching-learning methods, felt fear of change, saw many barriers hindering the implementation of the UDL strategy and did not see the need to overcome them. Generally speaking, they did not perceive the need for change, nor thought it made sense.

The experience of students-students and teacher-students collaboration shown in the data leads to the conclusion that there is a need to give students more chance for collaboration in changing groups, to widen their peer relations experience by working with diverse colleagues to learn from each other and for improving cooperation by varied educational and social experience in the classroom. This is because students prefer and choose collaboration only with some peers; they do not want to change groups. They also expect from teachers to take the leading position in the teaching-learning process, making them less self-directed and less aware of their personal goals for their education.

As for recognising barriers vs. strengths that might support transformation of the teaching-learning process in the class through implementation of the UDL approach towards inclusive education the data from interviews as well as from the survey were analysed. The formal barriers reflecting the system of education seemed very strong but some barriers inherent to personal beliefs and professional experience also appeared in teachers' opinions. Therefore, tools for changes towards inclusive education and UDL implementation might be seen in teachers' responsibility, their qualifications and their willingness to work for the students' success.

Further, the students' attitude to the school and to their duties seems promising and allows promoting changes by implementing UDL in the teaching-learning process in their daily school routines and might provide optimistic results for transformations into inclusive education.

Regardless of the fact that the vast majority of students felt safe at school and claimed that they liked attending it, more than half of them showed a reluctant attitude towards school duties. Students were shown to be aware of their learning styles and preferences, especially as regards the form of effort in class and its content.

Although students felt good at school and in the classroom, some of them were not motivated to learn, and most of them feared poor grades. This is evidenced by their statements, indicating their well-being at school, their individual preferences and learning opportunities, their interests and their attitude towards school duties. On the other hand, out of the four teachers surveyed, three of them had relatively long service and extensive professional experience; they admitted that the fact they had to answer questions posed to them led to a reflection that they do not know all students well enough and probably do not always apply appropriate educational strategies to them.

The research project revealed differences between the opinions of parents and students about the fact that the students themselves were positive about the school 
and the school situation and their well-being at school. According to the parents, their children's attitude towards school was positive. However, slightly fewer students than their parents might think admitted that they liked school and teachers and felt safe at school. Most students felt that they had at least a few friends among their peers at school, although they admitted that it was often not possible to make arrangements with their classmates after school. These findings might be perceived as typical if we refer to many studies of Polish researchers on similar topics (see the report of Domagała-Zyśk, 2018 or Chrzanowska, 2019).

The attitude of teachers and students was made legitimate by the focus on various barriers, which in their opinion hampered or even prevented UDL approach implementation. Among them, the most frequently mentioned were the barriers inherent in the education system, which are mainly related to official documents and regulations concerning education, teachers' feeling of being entangled with control and management rigors and personal barriers related to their beliefs and teachers' professional experience.

The research project undertaken in the selected school and class was mainly aimed at recognising the barriers and challenges in promoting the application of the UDL approach and supporting teachers and students in this area in the trials of optimising the teaching-learning process in a diverse class team towards transformation for inclusive education. It has been assumed that observing and documenting the ongoing changes will convince all participants of the survey about the value of the UDL approach as a line of thinking and organising education in a manner that favours its transformation. These benefits consist in creating a learning environment that is universal enough to enable each student, regardless of their abilities and difficulties, to participate fully in it and to make it an engine for optimal development, both individually and for the group to which they belong. Moreover, the aim was to begin the transformation of the attitude of students from passive recipients of learning content into active learners and builders of their own knowledge, able to control, plan, organise and manage the process of their own learning, responsible, creative and able to solve various problems in cooperation with others. For teachers, on the other hand, the benefits are seen in the remodelling of their thinking and pedagogical activity under the influence of the changes observed in the students, that is the transfer from the traditionally understood role of a teacher towards one who becomes a moderator and facilitator, creating optimal conditions for the teaching-learning process in a diversified group of students. This change is possible, among other things, with the use of the UDL approach, as confirmed by available literature sources (Capp, 2017; Paiva de Oliveira et al., 2019; Scott, 2018). The results of our research seem to be a strong argument for directing and supporting the class towards the change.

Despite no need for change expressed by students and teachers, the more that teachers and students expressed their interest in continuing joint efforts and research activities, the more we were convinced, as researchers, that the implementation of the UDL solutions will offer students and teachers an excellent opportunity to modify their regular routines in the teaching and learning process. Such experience, in turn, will be conducive to the implementation of the principles of inclusive 
education in the class under study, and then in the entire school. Moreover, we found it clear that the teachers showed awareness of the upcoming changes in the education system and its transformation towards inclusion.

\section{References}

Capp, M. J. (2017). The effectiveness of universal design for learning: A meta-analysis of literature between 2013 and 2016. International Journal of Inclusive Education, 8(21), 791-807.

Chrzanowska, I. (2019). Postawy wobec edukacji włączającej - jakie skutki? [Attitudes towards inclusive education-What effects?]. In I. Chrzanowska, G. Szumski (Eds.), Edukacja właczająca w przedszkolu i szkole [Inclusive education at kindergarden and school] (pp. 44-53). Warsaw: Wydawnictwo FRSE (FRSE Publishers).

Creswell, J.W. (2013). Projektowanie badań naukowych. Metody jakościowe, ilościowe $i$ mieszane [Design of scientific research. Metody jakościowe, ilościowe i mieszane]. Kraków: Wydawnictwo Uniwersytetu Jagiellońskiego (Jagiellonian University Publishing House).

Czerepaniak-Walczak, M. (2006). Pedagogika emancypacyjna. Rozwój świadomości krytycznej czlowieka [Emancipation pedagogy: The development of human critical awareness]. Gdańsk: Gdańskie Wydawnictwo Psychologiczne (Gdańsk Psychological Publishers).

Czerepaniak-Walczak, M. (2014). Badanie w działaniu w kształceniu i doskonaleniu nauczycieli (Research in action in teacher education and training). Przeglad Badań Edukacyjnych (Educational Research Review), 19(2), 181-194.

Domagała-Zyśk, E. (2018). Uczniowie z niepetnosprawnościami w szkołach ogólnodostępnych $i$ integracyjnych $w$ polskich badaniach naukowych. Część I - artykuty z polskich czasopism naukowych 2013-2017 (Pupils with disabilities in mainstream and integrated schools in Polish research. Part I-Articles from Polish scientific journals 2013-2017). Warszawa: MEN (Ministry of Education Publishing House).

Dyduch, E. (2012). System kształcenia specjalnego dzieci, młodzieży i dorosłych osób z niepełnosprawnością intelektualną (Special education system for children, young people and adults with mental retardation). In K. Bobińska, T. Pietras, P. Gałecki (Eds.), Niepetnosprawność intelektualna - etiopatogeneza, epidemiologia, diagnoza, terapia [Mental retardation Etiopathogenesis, epidemiology, diagnosis, therapy] (pp. 587-643). Wrocław: Continuo.

Dziennik Ustaw [Journal of Laws]. (2015). Poz. [item] 1113. Rozporzadzenie Ministra Edukacji Narodowej (Ordinance of Minister of National Education). http://isap.sejm.gov.pl/isap.nsf/ download.xsp/WDU20150001113/O/D20151113.pdf.

Gajdzica, Z. (2014). Kategorie sukcesów w opiniach nauczycieli klas integracyjnych jako przyczynek do poszukiwania koncepcji edukacji integracyjnej [Key success factors in the opinions of teachers of integrated forms as a contribution to the search for a concept of integrated education]. Kraków: Oficyna Wydawnicza ,Impuls” ('Impuls' Publishing House).

Gajdzica, Z. (2019). Zasady organizacji kształcenia w edukacjach inkluzyjnych uczniów z niepełnosprawnością [Education organisational principles in inclusive education of students with disabilities]. Niepetnosprawność. Dyskursy Pedagogiki Specjalnej (Disability. Discourses of Special Education), 33, 26-39.

Janiszewska-Nieścioruk, Z. (2009). Problemy edukacji integracyjnej dzieci i młodzieży $z$ niepetnosprawnościa intelektualna [Issues of integrated education of children and youth with intellectual disability]. Kraków: Oficyna Wydawnicza "Impuls" ('Impuls' Publishing House).

Jastrzębska, E. (2011). Strategie psychodydaktyki twórczości w ksztatceniu językowym (na przykładzie języka francuskiego) [Strategies for the psychodiactics of creativity in linguistic education <using the example of French>]. Kraków: Oficyna Wydawnicza "Impuls" (Impuls' Publishing House). 
Klus-Stańska, D. (2019). Wiedza osobista uczniów jako punkt zwrotny w teorii i praktyce dydaktycznej [Students' personal knowledge as a turning point in didactic theory and practice]. Kwartalnik Pedagogiczny (The Pedagogical Quarterly), 1(251), 7-20.

Knasiecka-Falbierska, K. (2013). Nauczyciel w przestrzeni [Teacher in space <illusio>]. In M. Dudzikowa \& K. Knasiecka-Falbierska (Eds.), Sprawcy i/lub ofiary działań pozornych $w$ edukacji szkolnej [Perpetrators and/or victims of bogus activities in school education] (pp. 187-203). Kraków: Oficyna Wydawnicza “Impuls” ('Impuls' Publishing House).

Kubinowski, D. (2010). Jakościowe badania pedagogiczne. Filozofia. Metodyka. Ewaluacja [Qualitative pedagogical studies. Philosophy. Methodology. Evaluation]. Lublin: The Publishing House of Maria Curie-Skłodowska University.

Kujawiński, J. (2010). Ewolucja szkoły i jej wspótczesna wizja [The evolution of the school and its contemporary vision]. Poznań: Wydawnictwo Uniwersytetu Adama Mickiewicza (Publishing House of Adam Mickiewicz University).

Kupisiewicz, C.z., \& Kupisiewicz, M. (2009). Słownik pedagogiczny [Pedagogical dictionary]. Warszawa: Wydawnictwo Naukowe PWN (Polish Scientific Publishers).

Markowska, B., \& Szafraniec, H. (1980). Podręcznik do Arkusza Zachowania się Ucznia. Testy psychologiczne w poradnictwie wychowawczo-zawodowym [A handbook for the student's sheet of conduct: Psychological tests in educational and vocational guidance)]. Warsaw: PWN (Polish Scientific Publishers).

Meyer, A., Rose, D. H., \& Gordon, D. (2014). Universal design for learning. Theory and practice. CAST Professional Publishing.

Okoń, W. (2004). Nowy słownik pedagogiczny [New pedagogical dictionary]. Warszawa: Wydawnictwo Akademickie ,Żak” ('Żak' Scholar Publishing House).

Paiva de Oliveira, A. R., Abreu de van Munster, M., \& Gonçalves, A. G. (2019). Universal design for learning and inclusive education: A systematic review in the international literature. Revista Brasileira de Educacao Especial Bauru, 25(4), 627-640.

Parys, K. (2007). Problemy integracji szkolnej w badaniach empirycznych - przegląd materiałów pokonferencyjnych [Issues of school integration in empirical research - An overview of conference materials]. In: Z. Janiszewska-Nieścioruk (Ed.), Problemy edukacji integracyjnej dzieci i mtodzieży z niepetnosprawnościa intelektualna [Issues of integrated education of children and youth with intellectual disability] (pp. 233-278). Kraków: Oficyna Wydawnicza "Impuls" ('Impuls' Publishing House).

Pilch, T., \& Bauman, T. (2010). Zasady badań pedagogicznych. Strategie ilościowe i jakościowe [Pedagogical research principles. Quantitative and qualitative strategies]. Warsaw: Wydawnictwo Akademickie "Żak” ( 'Żak'Academic Publishers).

Półturzycki, J. (2014). Dydaktyka dla nauczycieli [Didactics for teachers]. Toruń: Wydawnictwo Adam Marszałek (Adam Marszałek Publishing House).

Sagor, R. (2008). Badanie przez działanie. Jak wspólnie badać, żeby lepiej uczyć [Research through action. How to do research jointly to teach better]. Warsaw: Centrum Edukacji Obywatelskiej (Centre for Citizenship Education).

Scot, L. A. (2018). Barriers with implementing a universal design for learning framework. Inc, 6(4), 274-286.

Sendyk, M. (2001). Społeczne przystosowanie dzieci z poczuciem sieroctwa duchowego [Social adaptation of children with a sense of spiritual orphanage]. Kraków: Oficyna Wydawnicza "Impuls" ('Impuls' Publishing House).

Silberman, M. (2005). Uczymy się uczyć [We learn to learn]. Gdańsk: Gdańskie Wydawnictwo Psychologiczne (Gdańsk Publishing House).

Śliwerski, B. (2013). Pozory sprawstwa reform oświatowych III RP [Appearances of the educational reforms of the Third Republic of Poland]. In M. Dudzikowa, K. Knasiecka-Falbierska (Eds.), Sprawcy i/lub ofiary działań pozornych w edukacji szkolnej [Perpetrators and/or victims of bogus activities in school education] (pp. 103-130). Kraków: Oficyna Wydawnicza "Impuls" ('Impuls' Publishing House). 
Szmidt, K. J., \& Modrzejewska-Świgulska, M. (2015). Walidacja komunikacyjna w analizie wyników badań pedagogicznych [Communication validation in handing the results of pedagogical research]. Przeglad Badań Edukacyjnych (Educational Research Review), 2(19), 235-255.

Sztumski, J. (1995). Wstęp do metodologii i technik badań spotecznych [Introduction to social research methodologies and techniques]. Katowice: Wydawnictwo Śląsk (The Silesia Publishers).

Szumski, G. (2006). Integracyjne ksztatcenie niepetnosprawnych [Inclusive education for the disabled]. Warszawa: Wydawnictwo Naukowe PWN (PWN Scientific Publishers).

Szumski, G. (2019). Koncepcja edukacji włączającej [Inclusive education concept]. In I. Chrzanowska, G. Szumski (Eds.), Edukacja właczająca w przedszkolu i szkole [Inclusive education at kindergarten and school] (pp. 14-25). Warszawa: Wydawnictwo FRSE (FRSE Publishers).

Szymańska, M. (2018). Badania w działaniu (Research in action). In M. Ciechowska, M. Szymańska (Eds.), Wybrane metody jakościowe w badaniach pedagogicznych [Selected qualitative methods in pedagogical research] (pp. 227-273). Kraków: Wydawnictwo WAM (The WAM Publishers).

Szymańska, M., Ciechowska, M., Pieróg, K., \& Gołąb, S. (Eds.) (2018). Badania w działaniu w praktyce pedagogicznej (Research in action in pedagogical practice). In Wybrane przyktady [Research in action in pedagogical practice: Selected examples]. Kraków: Wydawnictwo Naukowe Akademii Ignatianum (Ignatianum Academy Scientific Publishers).

Zamkowska, A. (2009). Wsparcie edukacyjne uczniów z upośledzeniem umysłowym $w$ stopniu lekkim $w$ różnych formach kształcenia na I etapie edukacji [Educational support for students with mild mental retardation in various forms of education at the first stage of education]. Radom: Wydawnictwo Politechniki Radomskiej (The Radom University of Technology Publishers)

Open Access This chapter is licensed under the terms of the Creative Commons Attribution 4.0 International License (http://creativecommons.org/licenses/by/4.0/), which permits use, sharing, adaptation, distribution and reproduction in any medium or format, as long as you give appropriate credit to the original author(s) and the source, provide a link to the Creative Commons license and indicate if changes were made.

The images or other third party material in this chapter are included in the chapter's Creative Commons license, unless indicated otherwise in a credit line to the material. If material is not included in the chapter's Creative Commons license and your intended use is not permitted by statutory regulation or exceeds the permitted use, you will need to obtain permission directly from the copyright holder.

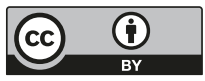

